\title{
Sediment community responses to marine vs. terrigenous organic matter in a submarine canyon
}

\author{
W. R. Hunter ${ }^{1,3}$, A. Jamieson ${ }^{1}$, V. A. I. Huvenne ${ }^{2}$, and U. Witte ${ }^{1}$ \\ ${ }^{1}$ Oceanlab, University of Aberdeen, Newburgh, Aberdeenshire, AB41 6AA, UK \\ ${ }^{2}$ National Oceanography Centre, Southampton, European Way, Southampton, SO14 3ZH, UK \\ ${ }^{3}$ Present Address: Department of Limnology, Universität Wien, Althanstrasse 14, 1090 Vienna, Austria \\ Correspondence to: W. R. Hunter (william.hunter@univie.ac.at)
}

Received: 25 July 2012 - Published in Biogeosciences Discuss.: 22 August 2012

Revised: 27 November 2012 - Accepted: 10 December 2012 - Published: 8 January 2013

\begin{abstract}
The Whittard Canyon is a branching submarine canyon on the Celtic continental margin, which may act as a conduit for sediment and organic matter (OM) transport from the European continental slope to the abyssal sea floor. In situ stable-isotope labelling experiments were conducted in the eastern and western branches of the Whittard Canyon, testing short-term (3-7 days) responses of sediment communities to deposition of nitrogen-rich marine (Thalassiosira weissflogii) and nitrogen-poor terrigenous (Triticum aestivum) phytodetritus. ${ }^{13} \mathrm{C}$ and ${ }^{15} \mathrm{~N}$ labels were traced into faunal biomass and bulk sediments, and the ${ }^{13} \mathrm{C}$ label traced into bacterial polar lipid fatty acids (PLFAs). Isotopic labels penetrated to $5 \mathrm{~cm}$ sediment depth, with no differences between stations or experimental treatments (substrate or time). Macrofaunal assemblage structure differed between the eastern and western canyon branches. Following deposition of marine phytodetritus, no changes in macrofaunal feeding activity were observed between the eastern and western branches, with little change between 3 and 7 days. Macrofaunal $\mathrm{C}$ and $\mathrm{N}$ uptake was substantially lower following deposition of terrigenous phytodetritus with feeding activity governed by a strong $\mathrm{N}$ demand. Bacterial $\mathrm{C}$ uptake was greatest in the western branch of the Whittard Canyon, but feeding activity decreased between 3 and 7 days. Bacterial processing of marine and terrigenous $\mathrm{OM}$ were similar to the macrofauna in surficial $(0-1 \mathrm{~cm})$ sediments. However, in deeper sediments bacteria utilised greater proportions of terrigenous OM. Bacterial biomass decreased following phytodetritus deposition and was negatively correlated to macrofaunal feeding activity. Consequently, this study suggests that macrofaunal-bacterial interactions influence benthic $\mathrm{C}$ cy-
\end{abstract}

cling in the Whittard Canyon, resulting in differential fates for marine and terrigenous OM.

\section{Introduction}

The primary energy source for life in deep-sea sediments comes via episodic depositions of phytoplankton-derived detritus (phytodetritus) as particulate organic matter (POM) (Lampitt et al., 2001). These episodic POM depositions stimulate rapid feeding and reproductive responses by the benthic faunal and microbial assemblages, mediating carbon cycling within deep-sea sediments (Gooday, 2002; Smith et al., 2010). Globally, between 600 and 6000 submarine canyons are known to incise the continental margins at bathyal depths (200-3000 m) (De Leo et al., 2010; Harris and Whiteway, 2011). Submarine canyons can act as conduits for the transport of sediment from the continental shelf $(0-200 \mathrm{~m})$ to the abyssal sea floor $(\sim 4000 \mathrm{~m})$ via slope failures, sediment slumps, and through the action of dense water cascading events, tidal forcing and storm-induced gravity flows (e.g. de Stitger et al., 2007; Arzola et al., 2008; Tesi et al., 2008, 2010; Pasqual et al., 2011). Therefore, submarine canyons may be subjected to intermittent disturbance events resulting in temporary accumulation of allochthonous sediments and enhanced inputs of terrigenous POM (i.e. derived from the land masses), relative to the surrounding continental margins.

Within deep-sea sediments, bacterial and macrofaunal (size range $250-1000 \mu \mathrm{m}$ ) assemblages control short-term processing of POM, following a deposition event (e.g. Witte

Published by Copernicus Publications on behalf of the European Geosciences Union. 
et al., 2003b; Buhring et al., 2006; Gontikaki et al., 2011b). Macrofauna respond rapidly to POM deposition, contributing directly to ecosystem-scale carbon cycling through ingestion, assimilation and respiration (e.g. Aberle and Witte, 2003; Gontikaki et al., 2011a; Hunter et al., 2012a). Bioturbation by the fauna indirectly influences benthic $\mathrm{C}$ cycling, providing routes for the rapid subduction of $\mathrm{POM}$ into deeper sediment layers (e.g. Levin et al., 1997). Bacterial assemblages often display a retarded response to POM deposition relative to the fauna (e.g. Witte et al., 2003a, b; van Nugteren et al., 2009). During POM deposition events, bacterial assemblages exhibit increases in extracellular enzyme production, which drives extracellular hydrolysis of the organic matter. Bacterial growth subsequently follows enzyme production, if the OM source provides a sufficient source of energy (carbon) and limiting nutrients (e.g. nitrogen, phosphorus, iron, etc.) (Thingstad, 1987; Boetius and Lochte, 1994, 1996). Bacteria exhibit a wide range of digestive mechanisms and are capable of processing even recalcitrant (low quality) organic matter, such as lignins and celluloses (e.g. Kristensen and Holmer, 2001). Thus, resource partitioning represents an important interaction between benthic macrofaunal and bacterial assemblages, with macrofauna controlling bacterial access to organic matter sources (e.g. van Nugteren et al., 2009; Hunter et al., 2012b). Faunal bioturbation also influences bacterial assemblages, through creation and destruction of microhabitats, and stimulation of aerobic metabolism (Giblin et al., 1995). Macrofaunal grazing typically accounts for $<10 \%$ of bacterial production, maintaining bacterial biomass at a steady state (Kemp, 1987), with ecosystem models predicting low transfer of carbon from bacteria to fauna in deep-sea sediments (Rowe et al., 2008; van Oevelen et al., 2011a, b).

In submarine canyons, variations in the frequency of disturbance events and resource availability influence the structure of sediment macrofaunal assemblages (Cunha et al., 2011; Paterson et al., 2011). Canyon sediments receive increased POM inputs via both vertical transport, through the water column, and lateral transport, through slope processes. Consequently, canyons may support higher bacterial and faunal densities than surrounding bathyal and abyssal sediments (Vetter and Dayton, 1998; Duineveld et al., 2001; EscobarBriones et al., 2008; De Leo et al., 2010; Cunha et al., 2011). In the Whittard Canyon (Northeast Atlantic), Duineveld et al. (2001) report enhanced sediment community oxygen consumption (SCOC) within canyon sediments. The vertical flux of POM was comparable between the canyon and the surrounding continental margin, suggesting that lateral inputs of sediment provide an important POM source into the canyon (Duineveld et al., 2001). Similarly, in the Congo canyon high POM inputs, carried by turbidity currents, result in enhanced SCOC and carbon remineralisation (Rabouille et al., 2009).

Stable-isotope labelling experiments provide a powerful tool to quantify the rates and pathways of organic matter processing at the ecosystem scale. These methods allow the short-term fate of organic carbon to be empirically traced, in situ, within deep sea sediments, using ${ }^{13} \mathrm{C}$-labelled phytodetritus (e.g. Witte et al., 2003a, b). These in situ methods overcome the practical challenges of experimental work in deep-sea sediments, mitigating potential artefacts of changing pressure and temperature associated with shipboard and in vitro studies (Hall et al., 2007). At the ecosystem-scale, carbon processing is linked to the availability of organic nitrogen as a limiting nutrient (Vitousek and Howarth, 1991). Dual-labelling $\left({ }^{13} \mathrm{C}:{ }^{15} \mathrm{~N}\right)$ experiments demonstrate that ecological demand for organic nitrogen is an important driver of OM recycling in marine sediments (e.g. Evrard et al., 2010). This is important within the faunal assemblages, where feeding behaviour is strictly controlled by organismal C:N budgets (Hunter et al., 2012a). Data from stable-isotope labelling experiments is particularly powerful during the development of ecosystem models, constraining model uncertainty by between 50 and $60 \%$ (van Oevelen et al., 2006). Gontikaki et al. (2011c) integrated stable-isotope labelling data into a benthic food web model for the bathyal Faroe-Shetland channel $(1080 \mathrm{~m})$, revealing that benthic bacteria contribute $\sim 50 \%$ of macrofaunal carbon requirements. This indicates that faunal grazing upon bacteria may represent an underestimated carbon cycling pathway within deep-sea sediments.

It is predicted that climate change will increase the frequency of extreme weather events potentially resulting in increased sediment and OM inputs from the European continental shelf into submarine canyons (e.g. Canals et al., 2006; de Stitger et al., 2007; Arzola et al., 2008; Pasqual et al., 2011). Thus, there is a requirement to understand the dynamics of OM recycling in canyon sediment communities. The present study used the deep-sea Remotely Operated Vehicle (ROV) ISIS to conduct in situ, short-term ${ }^{13} \mathrm{C}:{ }^{15} \mathrm{~N}-$ labelling experiments at two stations in the eastern and western branches of the Whittard Canyon. The study aims to test the hypotheses: (1) that differences in the sediment community between the two canyon branches will influence the fate of freshly deposited phytodetritus, and (2) that processing of marine and terrigenous phytodetritus by the sediment community will be dictated by the relative availability of organic $\mathrm{N}$ within each POM source. The study will also investigate potential relationships between macrofaunal feeding activity and bacterial biomass as evidence of faunal-bacterial interactions within the sediments of the Whittard Canyon.

\section{Materials and methods}

\subsection{Study area}

The Whittard Canyon is a submarine canyon on the Celtic continental margin, southeast of the Goban Spur. Prominent eastern and western canyon branches extend from $\sim 200 \mathrm{~m}$ on the continental margin down to the Whittard Channel and Celtic fan at $\sim 4000 \mathrm{~m}$ (Fig. 1; Zaragosi et al., 2006). 


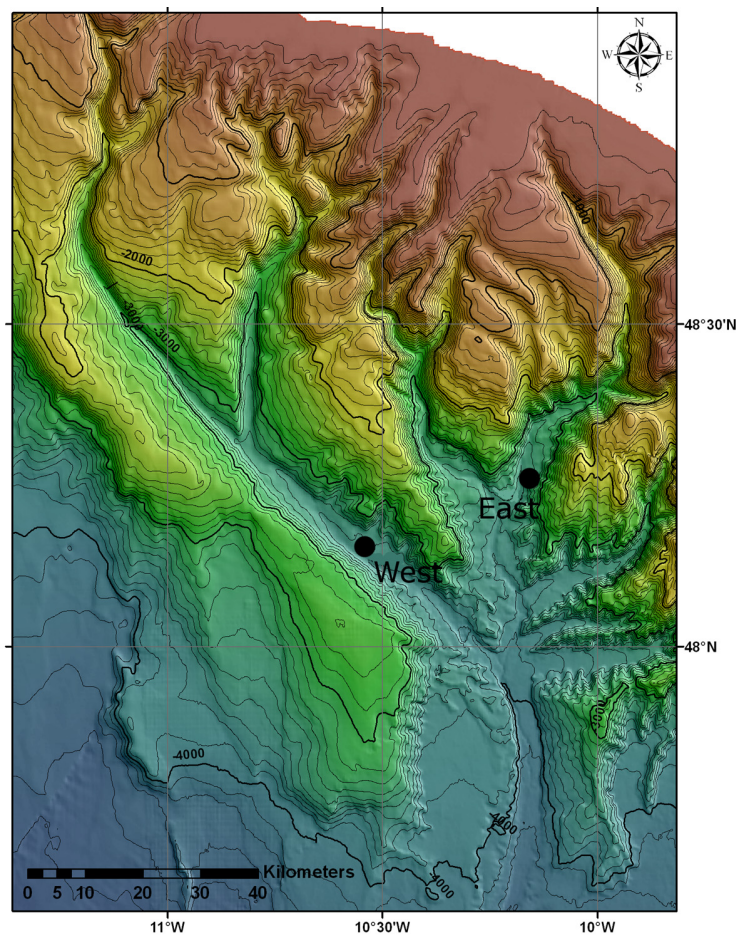

Fig. 1. Bathymetric map of the Whittard Canyon, indicating both of the experimental stations. Bathymetry data was kindly provided by the Geological Survey of Ireland (GSI-Dublin).

The upper reaches of the canyon are steep-sided, with wall heights of 700 to $800 \mathrm{~m}$ and coarser sediments. Finer sediments can be found in the lower canyon, where the different branches meet between $3600 \mathrm{~m}$ and $4000 \mathrm{~m}$ water depth. Extensive sediment transport through the Whittard Canyon occurred during sea-level lowstands, especially during deglaciation phases (Toucanne et al., 2008; Zaragosi et al., 2006). The present-day activity of the canyon is rather low, governed by small-scale slope failures, associated turbidity currents and residual sediment movement by internal waves and tides, with average current speeds of $6 \mathrm{~cm} \mathrm{~s}^{-1}$ and peak velocities of $16 \mathrm{~cm} \mathrm{~s}^{-1}$ sufficient to move fine sediments (Reid and Hamilton, 1990). In situ stable-isotope labelling experiments were conducted at two stations in the lower Whittard Canyon (Fig. 1, Table 1). Stations were located on sedimentary terraces, between 60 and $100 \mathrm{~m}$ above the central axis of the eastern and western canyon branches. Sediments in both the eastern and western branches were primarily composed of silt at depths $>3000 \mathrm{~m}$ (Otto and Balzer 1998; Duros et al., 2011). Stations were visited in June and July 2009 as part of RRS James Cook cruise JC036, and followed the spring phytoplankton bloom in the Northeast Atlantic Ocean (e.g. Billett et al., 1983; Lampitt et al., 2001).
Table 1. Environmental conditions at the Whittard Canyon experimental stations. Depth, temperature and salinity data were obtained from a CTD attached to the ROV ISIS.

\begin{tabular}{lll}
\hline Station & East & West \\
\hline Position & $48.2665^{\circ} \mathrm{N} ; 10.1579^{\circ} \mathrm{W}$ & $48.1557^{\circ} \mathrm{N} ; 10.5409^{\circ} \mathrm{W}$ \\
Depth $(\mathrm{m})$ & 3410 & 3595 \\
Temp $\left({ }^{\circ} \mathrm{C}\right)$ & 2.61 & 2.58 \\
Salinity & 34.93 & 34.93 \\
Sediment POC $(\%)$ & $0.696( \pm 0.047)$ & $0.526( \pm 0.046)$ \\
Sediment TN $(\%)$ & $0.098( \pm 0.006)$ & $0.076( \pm 0.007)$ \\
Sediment C:N & $7.102( \pm 0.166)$ & $6.889( \pm 0.132)$ \\
\hline
\end{tabular}

\subsection{Phytodetritus production}

Marine phytodetritus was produced from an axenic clone of the ubiquitous diatom Thalassiosira weissflogii (CCMP, Bigelow Marine Laboratories). Algae were cultured under a 16:8 light-dark regime $\left(\mathrm{Temp}=16^{\circ} \mathrm{C}\right.$; salinity $=35$; duration $=28$ days) in artificial seawater and $L 1$ culture medium enriched with $99 \%{ }^{13} \mathrm{C}$-bicarbonate $\left(\mathrm{NaH}^{13} \mathrm{CO}_{3}\right.$, Cambridge Isotope Laboratories) and $50 \%{ }^{15} \mathrm{~N}$-sodium nitrate $\left(\mathrm{Na}^{15} \mathrm{NO}_{3}\right.$, Cambridge Isotope Laboratories). Algae were harvested by centrifugation $(500 \mathrm{~g} \times 30 \mathrm{~min})$, sonicated $(2000 \mathrm{~Hz} ; 5 \mathrm{~min})$ and rinsed three times in ultrapure water (milli-Q) to remove inorganic salts and dissolved organic carbon (DOC). Harvested algae were lyophilised $\left(-60^{\circ} \mathrm{C}\right.$; $-0.0001 \mathrm{mbar} ; 24 \mathrm{~h}$ ) to produce marine phytodetritus labelled to 27.75 atom $\%{ }^{13} \mathrm{C} ; 33.70$ atom $\%{ }^{15} \mathrm{~N}$, with a C:N mass ratio of 4.06. Terrestrial phytodetritus was obtained from the lyophilised axenic ${ }^{13} \mathrm{C}:{ }^{15} \mathrm{~N}$-labelled leaves of the wheat Triticum aestivum (Cambridge Isotope Laboratories). Triticum aestivum leaves were milled, sonicated, rinsed three times in ultrapure water (milli-Q) and lyophilised, as described above, to produce the terrestrial phytodetritus. Terrestrial phytodetritus was labelled to 97 atom $\%{ }^{13} \mathrm{C}$; 97 atom $\%{ }^{15} \mathrm{~N}$, with a C:N ratio of 22.80 .

\subsection{Experimental design}

Stable-isotope labelling experiments were conducted in situ using Oceanlab spreader mesocosms. Each spreader consists of a transparent polycarbonate tube (diameter: $25 \mathrm{~cm}$, length: $30 \mathrm{~cm}$ ), with an acetal plastic lid. The lid of each spreader contains a cartridge of isotopically-labelled phytodetritus, which is released by depressing an elastically tensioned plunger. Spreaders were deployed by the ROV ISIS, releasing known doses of isotopically labelled phytodetritus onto replicate $0.049 \mathrm{~m}^{2}$ areas of seafloor (following Hunter et al., 2012a, b).

Three spreaders were deployed for both three and seven day incubations at the western station. Spreaders were deployed approximately $2 \mathrm{~m}$ apart on undisturbed areas of seafloor. Experiments commenced with the deposition of a fixed dose of ${ }^{13} \mathrm{C}:{ }^{15} \mathrm{~N}$ labelled $T$. weissflogii slurry (1000 $\left.\mathrm{mg} \mathrm{C} \mathrm{m}^{-2} ; 246 \mathrm{mg} \mathrm{N} \mathrm{m}^{-2}\right)$ onto 
the enclosed sediments. At the eastern station, the response of the benthic community to marine and terrestrial phytodetrital sources was investigated over three days. Triplicate spreaders were deployed as previously described, depositing fixed doses of either ${ }^{13} \mathrm{C}:{ }^{15} \mathrm{~N}$ labelled $T$. weissflogii $\left(1000 \mathrm{mg} \mathrm{C} \mathrm{m}^{-2} ; 246 \mathrm{mg} \mathrm{N} \mathrm{m}^{-2}\right)$ or T. aestivum ( $1000 \mathrm{mg} \mathrm{C} \mathrm{m}^{-2} ; 43.86 \mathrm{mg} \mathrm{N} \mathrm{m}^{-2}$ ) onto the sediment surface. Phytodetritus doses were equivalent to the annual POM inputs in the bathyal and abyssal NE Atlantic, ranging from 950 to $1210 \mathrm{mg} \mathrm{C} \mathrm{m}^{-2} \mathrm{yr}^{-1}$ and 120 to $190 \mathrm{mg} \mathrm{N} \mathrm{m}^{-2} \mathrm{yr}^{-1}$ (Lampitt et al., 2001). Experiments were terminated by removal of the spreader lids. Each spreader was subsampled using three $7 \mathrm{~cm}$ diameter push cores and recovered by the ROV. Cores were horizontally sectioned along the following intervals: $0-1,1-2,2-3,3-5,5-7,7-10 \mathrm{~cm}$, and allocated for macrofauna, bacterial or geochemical analysis. Three replicate background cores were taken at each station to provide natural stable isotope signatures of the fauna, bacteria and sediment organic matter. Loss of cores during the sampling operation resulted in the recovery of only one of the replicate 3-day incubations at the western station, two of the replicate marine phytodetritus incubations and two of the terrestrial phytodetritus incubations at the eastern station.

\subsection{Sample processing and data treatment}

Sectioned macrofaunal cores were wet-sieved through a $250 \mu \mathrm{m}$ mesh, using filtered sea water, and fixed in buffered $4 \%$ formaldehyde solution. The upper four sections $(0-1$, $1-2,2-3,3,5 \mathrm{~cm})$ were sorted under $\times 12$ and $\times 20$ magnification. Macrofauna were identified to family level and abundances recorded. Macrofauna were then rinsed in ultrapure water and pooled into three broad taxonomic groups (crustacea; polychaetes; other taxa) in silver cups for massspectrometry. Pooled macrofaunal samples were decarbonated by addition of 1 to 2 drops of analytical grade $6 \mathrm{~mol} \mathrm{~L}^{-1}$ hydrochloric acid $\left(\mathrm{HCl}_{\mathrm{aq}}\right)$ and dried to constant weight at $60{ }^{\circ} \mathrm{C}$. Sectioned bacterial and geochemical cores were homogenised and immediately frozen at $-80^{\circ} \mathrm{C}$. Following the cruise, sediment samples were lyophilised $\left(-60^{\circ} \mathrm{C}\right.$; -0.0001 mbar; $24 \mathrm{~h}$ ) prior to analysis. Lyophilised sediments were decarbonated by addition of excess $1 \mathrm{~mol} \mathrm{~L}^{-1} \mathrm{HCl}_{\mathrm{aq}}$, incubated for $24 \mathrm{~h}$ at $30^{\circ} \mathrm{C}$ in an acid-fumed environment (following Hedges and Stern, 1984) and dried to constant weight at $60^{\circ} \mathrm{C}$. The acidified sediments were then used to determine bulk sediment particulate organic carbon (POC), total nitrogen (TN), and penetration of the phytodetrital ${ }^{13} \mathrm{C}$ and ${ }^{15} \mathrm{~N}$ labels.

Organic carbon and nitrogen concentrations and isotopic ratios $\left({ }^{12} \mathrm{C} /{ }^{13} \mathrm{C}\right.$ and $\left.{ }^{14} \mathrm{~N} /{ }^{15} \mathrm{~N}\right)$ of the fauna and bulk sediments were determined on a PDZ Europa ANCA-GSL elemental analyser linked to a PDZ Europa 20-20 Isotope Ratio Mass Spectrometer (IRMS) (Sercon Ltd, Cheshire UK). Samples were combusted at $1000^{\circ} \mathrm{C}$ using helium $(\mathrm{He})$ as a carrier gas and analysed with the IRMS and internal standards adapted for low carbon samples. Isotope ratio data were expressed in $\delta$ units $\left(\% \circ\right.$ and used to estimate faunal ${ }^{13} \mathrm{C}$ and ${ }^{15} \mathrm{~N}$ uptake following Middelburg et al. (2000). Faunal ${ }^{13} \mathrm{C}$ and ${ }^{15} \mathrm{~N}$ atom $\%$ values were calculated by:

atom $\% X_{\text {sample }}=\left(\frac{\left(X_{\text {sample }} / 1000\right) \times R_{\text {standard }} \times 100+1}{\left(X_{\text {sample }} / 1000\right) \times R_{\text {standard }}+1}\right)$

where atom $\% X_{\text {sample is the }}{ }^{13} \mathrm{C}$ or ${ }^{15} \mathrm{~N}$ content of the sample (in atom \%), $X_{\text {sample }}$ is the isotopic ratio $\left(\delta^{13} \mathrm{C}\right.$ or $\left.\delta^{15} \mathrm{~N}\right)$ of the sample (\%o) and $R_{\text {standard }}$ is an international reference material: Vienna PeeDee Belemnite for C $\left(R_{\mathrm{VPDB}}=0.0112372\right)$; atmospheric nitrogen for $\mathrm{N}\left(R_{\text {atom } N}=0.0036765\right)$. Faunal ${ }^{13} \mathrm{C}$ values were corrected for the effects of formaldehyde preservation by adding $1 \%$ to each $\delta^{13} \mathrm{C}$-value (after Kaehler and Pakhomov, 2001). Excess ${ }^{13} \mathrm{C}$ and ${ }^{15} \mathrm{~N}$ concentrations in each sample were calculated by:

$E=\frac{\left(\text { atom } \% X_{\text {sample }}-\text { atom } \% X_{\text {background }}\right)}{100}$

where $E$ is the excess isotopic label, atom $\% X_{\text {sample }}$ is the atom $\%{ }^{13} \mathrm{C}$ or ${ }^{15} \mathrm{~N}$ of the sample, and atom $\% X_{\text {background }}$ is the atom $\%{ }^{13} \mathrm{C}$ or ${ }^{15} \mathrm{~N}$ of the background material (Table A1). Background ${ }^{13} \mathrm{C}$ and ${ }^{15} \mathrm{~N}$ values were determined from the natural isotopic signatures of macrofauna sampled at each station. Phytodetrital carbon (phyto $\mathrm{C}$ ) and nitrogen $($ phyto $\mathrm{N}$ ) uptake were calculated as the product of the excess isotopic label in each macrofaunal sample and the ${ }^{13} \mathrm{C}$ or ${ }^{15} \mathrm{~N}$ labelling of the phytodetrital source (in atom \%), and normalised to faunal biomass (biomass-specific uptake).

Polar lipid fatty acids (PLFAs) were extracted from spreader and background cores by a modified Bligh-Dyer extraction protocol (White et al., 1979). PLFAs were extracted from $9 \mathrm{~g}$ aliquots of lyophilised sediment using a single phase extraction mixture of chloroform, methanol and citrate buffer $(1: 2: 0.8$ by volume) for $2 \mathrm{~h}$. The lipid extract was sequentially fractioned on silicic acid columns $(6 \mathrm{~mL}$ ISOLUTE SIS PE columns) by elution with chloroform (neutral lipids), acetone (glyolipids) and methanol (polar lipids). PLFAs were transmethylated by alkaline methanolysis to yield fatty acid methyl esters (FAMEs).

Individual FAMEs were identified and quantified on an Agilent $6890 \mathrm{~N}$ gas chromatograph flame ionisation detector. Isotopic ratios $\left({ }^{12} \mathrm{C} /{ }^{13} \mathrm{C}\right)$ of individual FAMEs were determined using a GC Trace Ultra coupled with a GC Combustion III to a Delta V Advantage isotope ratio mass spectrometer (Thermo-Finnegan). Carbon isotope ratios were expressed in delta notation and converted to atom $\%$ values by Eq. (1). ${ }^{13} \mathrm{C}$ values of the background and experimental PLFAs were obtained by correction of the FAME isotope ratios for the extra $\mathrm{C}$ added during alkaline methanolysis (following Crossman et al., 2004). Excess ${ }^{13} \mathrm{C}$ within each PLFA was calculated by Eq. (2) and phyto $\mathrm{C}$ incorporation into the PLFAs calculated as the product of the excess ${ }^{13} \mathrm{C}$, PLFA 
concentration and ${ }^{13} \mathrm{C}$ labelling of the phytodetrital source (atom \%).

Bacterial biomass and phyto $\mathrm{C}$ incorporation were calculated from the bacterial PLFAs $i 15: 0, i 15: 0, i 17: 0, i 17$ : 0 cy, 12-Me-17:0, 10-Me-18:0; 19:0 cy (Boschker and Middelburg, 2002) as:

$$
I_{\text {bactera }}=\sum\left(\frac{I_{\mathrm{PLFA}}}{[a \times b]}\right)
$$

where $I_{\text {bacteria }}$ is the bacterial biomass or phyo $\mathrm{C}$ incorporation into bacterial biomass; I PLFA is the concentration of a bacteria-specific PLFA or its phyto C concentration; $a$ is the PLFA concentration in bacteria within marine sediments ( $\sim 0.056 \mathrm{~g}$ of C PLFA per $\mathrm{g}$ of $\mathrm{C}$ biomass) (Brinch-Iversen and King, 1990); and $b$ is the average contribution of bacterial PLFAs to the sediment PLFA pool (20\%) (calculated from Rajendran et al., 1993, 1994; Boschker et al., 1998; Middelburg et al., 2000; Stoeck et al., 2002). Bacterial phyto $\mathrm{C}$ incorporation was then normalised to biomass to allow comparison between stations. Data are publicly available via PANGAEA (http://doi.pangaea.de/10.1594/PANGAEA. 803858).

\subsection{Data analysis}

All analyses were carried out in R 2.9.2 (R Development Core Team, 2009) using the VEGAN (Oksanen et al., 2009), MASS (Venables and Ripley, 2002) and mblm (Komsta, 2007) packages. Data were graphically explored to assess their fits to assumptions of normality and homoscedasticity (Zuur et al., 2010). Differences in faunal abundance between sediment depth fractions and experimental stations were investigated by nested analysis of variance (ANOVA), following square root transformation. Post-hoc testing was conducted using Tukey's Honest Significant Difference (HSD) test, at a significance level of $p<0.05$ (Quinn and Keough, 2002).

Differences in macrofaunal assemblage structure were investigated between stations, using multivariate techniques. A Bray-Curtis dissimilarity index was constructed from family level count data, transformed by $\sqrt{ }(x+0.1)$ to reduce the influence of highly abundant taxa (Clarke, 1993). Multivariate normality was investigated by graphical exploration and a randomisation test (1000 permutations; $p<0.05)$ of the beta dispersions (Anderson, 2006). Differences in faunal assemblage structure between the eastern and western canyon branches were investigated using non-metric Multidimensional Scaling (nMDS) and non-metric permutational multivariate analysis of variance (npermMANOVA) at a significance level of $p<0.05$ (1000 permutations) (Anderson, 2001).

Relationships between macrofaunal activity (biomassspecific ${ }_{\text {phyto }} \mathrm{C}$ and ${ }_{\text {phyto }} \mathrm{N}$ uptake) and bacterial biomass were tested using Theil-Sen single median regression (Sen, 1968). This is a robust linear regression technique, which is resistant to the influence of outliers and violations of the assumptions of normality and homogenous variance. These relationships were investigated across both experimental stations, using the background sediment samples as a time 0 control.

\section{Results}

\subsection{Environmental conditions}

Position and environmental conditions at each of the stations are summarised in Table 1 . The present study did not include a detailed granulometric analysis. Sediments at both stations were composed primarily of silt and fine sands. Bioturbation was evident at both stations, with burrow holes visible on the sediment surface. There were no differences in sediment POC content or C:N ratios between stations. Sedimentary $\mathrm{TN}$ content was greater at the station in the eastern canyon branch. Following deposition of phytodetritus at each station, $\delta^{13} \mathrm{C}$ and $\delta^{15} \mathrm{~N}$ profiles show mixing of the isotopic labels down to $5 \mathrm{~cm}$ depth (Fig. 2). No differences were observed in $\delta^{13} \mathrm{C}$ or $\delta^{15} \mathrm{~N}$ profiles as a consequence of station. In the eastern branch, no differences in mixing were recorded between the marine and terrestrial phytodetritus treatments. At the western branch station, experimental duration influenced the $\delta^{13} \mathrm{C}$ and $\delta^{15} \mathrm{~N}$ profiles, with a reduction in the quantity of isotopic labels recovered from the $0-1 \mathrm{~cm}$ sediment layer, between three and seven days.

\subsection{Macrofaunal assemblages}

The description of the macrofaunal assemblage at each of the stations is based upon both replicate background cores and spreader experiments. Sample sizes were $n=9$ at the eastern station and $n=8$ at the western station. Overall, mean abundances were $5352( \pm 2583)$ ind $\mathrm{m}^{-2}$ at the eastern station, and $3416( \pm 2069)$ ind $\mathrm{m}^{-2}$ at the western station. Macrofaunal abundance was significantly greater at the eastern station and exhibited significant differences as response to sediment depth. No interactions between station and sediment depth were observed to influence macrofaunal abundance (Table 2, Fig. 3). Post-hoc testing reveal significantly greater abundances of macrofauna at the eastern station $(p=0.039)$, and in the upper $(0-1,1-2 \mathrm{~cm})$ sediment layers compared with deeper sediments $(2-3,3-5 \mathrm{~cm})(p<0.050)$. Macrofaunal biomass exhibited high within-station variability, with no differences in biomass observable between the eastern and western canyon branches (Table B1).

The macrofaunal assemblage differed between the eastern and western branches of the Whittard Canyon (Fig. 4). At the western station, polychaetes and crustaceans contributed a higher proportion of the macrofaunal assemblage, whilst macrofaunal-sized nematodes contribute the highest proportion of the assemblage at the eastern stations (Fig. 4a). In terms of polychaete families, the western station is characterised by a higher proportion of Amphinomidae, while 

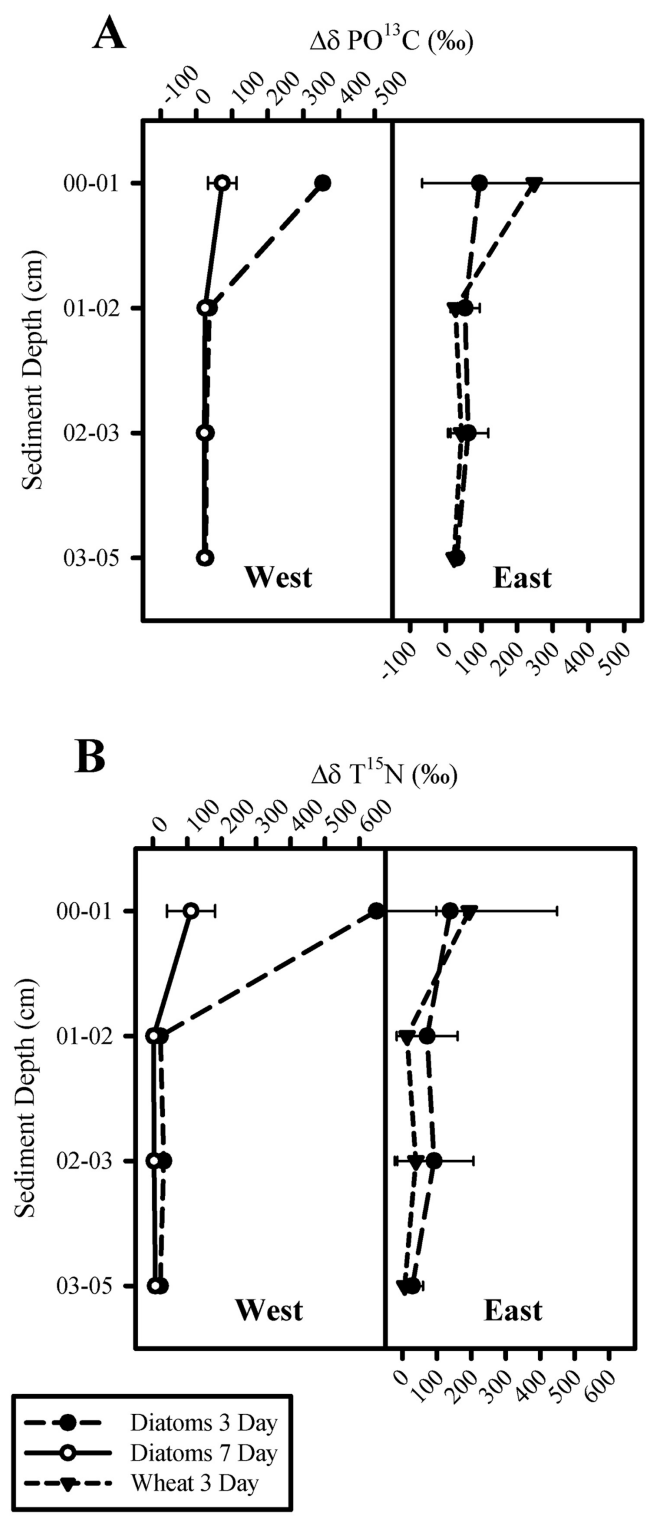

Fig. 2. Specific labelling (mean \pm standard deviation) of (A) particulate organic carbon $\left(\Delta \delta \mathrm{PO}^{13} \mathrm{C}\right)$ and $(\mathbf{B})$ total nitrogen $\left(\Delta \delta \mathrm{T}^{15} \mathrm{~N}\right)$ within the sediments at both the eastern and western Whittard Canyon stations.

cirratuliae and spionidae contributed highly to the assemblage at the eastern stations (Fig. 4b). Non-metric Multidimensional Scaling reveals macrofaunal samples from the Whittard Canyon to form two station-specific groups (Fig. 5). These differences in assemblages between the eastern and western canyon branches were statistically significant (Table 3), with station-specific effects explaining $21 \%$ of the variance in macrofaunal assemblage structure.

At the western station, there was little change in phyto $\mathrm{C}$ and ${ }_{\text {phyto }} \mathrm{N}$ processing over time by either the crustaceans or polychaetes. However, phyto $\mathrm{C}$ and ${ }_{\text {phyto }} \mathrm{N}$ uptake by other taxa decreased between 3 and 7 days (Fig. 6). At the eastern sta-
Table 2. Two-way analysis of variance testing for differences in macrofaunal abundance (square root transformed) between sediment depth fractions and stations.

\begin{tabular}{lrrrrr}
\hline & $\mathrm{d} f$ & SS & MS & $F$ & $p$ \\
\hline Sed. Depth & 3 & 11250.8 & 3750.3 & 16.9 & $<0.001 * * *$ \\
Station & 1 & 986.3 & 986.3 & 4.5 & 0.039 \\
Sed.Depth/Station & 3 & 210.8 & 70.3 & 0.3 & 0.812 \\
Residuals & 60 & 13239.1 & 220.7 & & \\
\hline
\end{tabular}

Table 3. Nonmetric permutational MANOVA testing differences in macrofaunal assemblage structure between stations. nperMANOVA was based upon a Bray-Curtis dissimilarity matrix of macrofaunal abundances, tested over 1000 permutations.

\begin{tabular}{lrrrrrr}
\hline & $\mathrm{d} f$ & $\mathrm{SS}$ & $\mathrm{MS}$ & pseudo-F & $R^{2}$ & $p$ \\
\hline Station & 1 & 0.359 & 0.359 & 4.077 & 0.213 & $0.01^{* *}$ \\
Residuals & 15 & 1.321 & 0.088 & & 0.786 & \\
\hline
\end{tabular}

tion, the macrofauna consumed greater quantities of phyto $\mathrm{C}$ and phyto $\mathrm{N}$ from the marine phytodetritus, compared with the terrigenous material. However, biomass-specific phyto $\mathrm{C}$ and phyto $\mathrm{N}$ uptake of marine and terrigenous phytodetritus sources exhibited no differences between the three taxonomic groups (Fig. 6). Relationships amongst macrofaunal phyto $\mathrm{C}$ and ${ }_{\text {phyto }} \mathrm{N}$ uptake were explored by the calculation of biomass-specific phyto $\mathrm{C}$ :phyto $\mathrm{N}$ uptake ratios (Fig. 7). These ranged between 1 and 5 at the western station and from 0.1 to 4 at the eastern station and indicate preferential incorporation of phyto $\mathrm{N}$ into the macrofaunal biomass, relative to $\mathrm{C}: \mathrm{N}$ ratios of the marine (4.06) and terrestrial (22.80) phytodetritus. However, the crustaceans are observed to exhibit higher phyto $\mathrm{C}$ :phyto $\mathrm{N}$ ratios, indicating a greater demand for phyto $\mathrm{C}$ within this taxonomic group.

\subsection{Bacterial assemblages}

Bacterial biomass exhibits no differences between the eastern and western stations, nor any differences between sediment depth intervals. Following phytodetritus deposition, bacterial biomass was observed to decrease over 7 days at the western station, and over 3 days at the eastern station (Fig. 8).

At the western station, incorporation of phyto $\mathrm{C}$ into bacterial biomass decreased between the 3- and 7-day incubations. Within both the 3- and 7-day experiments, bacterial phyto $\mathrm{C}$ incorporation was greatest in the $0-1 \mathrm{~cm}$ sediment layer and the relative contribution of bacteria in the three sediment layers exhibited little difference between 3 and 7 days (Fig. 9). At the eastern station, greater bacterial phyto $\mathrm{C}$ incorporation was observed from marine phytodetrital source in the $0-1 \mathrm{~cm}$ sediment layer. In contrast, bacterial incorporation of phyto $\mathrm{C}$ from the terrigenous phytodetritus was higher in the deeper $(1-2,2-3 \mathrm{~cm})$ sediment layers (Fig. 9). 


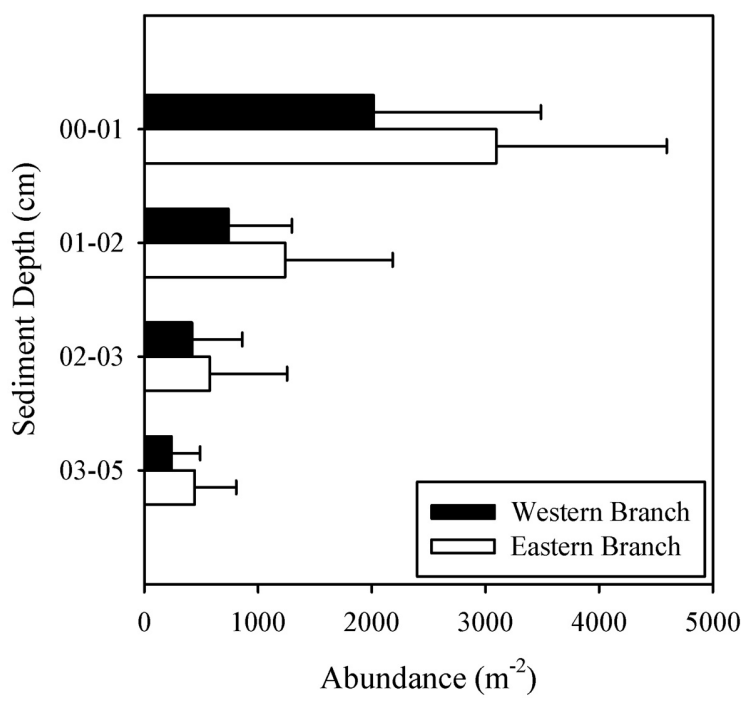

Fig. 3. Vertical distribution of total macrofauna abundances (mean \pm standard deviation) at the eastern and western branch stations.

Relationships between the macrofaunal feeding activity and bacterial biomass were explored across the two experimental stations using median-based linear regression (Fig. 10). These show strong negative correlations between bacterial biomass and macrofaunal activity, with biomassspecific phyto $\mathrm{C}$ and ${ }_{\text {phyto }} \mathrm{N}$ uptake by the macrofauna accounting for between 30 and $35 \%$ of the variation in bacterial biomass across the two experimental stations.

\section{Discussion}

\subsection{Methodological considerations}

Recovery of sediments from the deep sea results in changes in temperature and pressure that influence carbon and nitrogen fluxes, and oxygen penetration (e.g. Hall et al., 2007). In the Whittard Canyon, stable-isotope labelling experiments were conducted in situ at $\sim 3500 \mathrm{~m}$, minimizing sedimentrecovery artefacts upon macrofaunal and bacterial activity. Experimental mesocosms were deployed, sampled and recovered by the ROV ISIS on regions of undisturbed sediment at the sea floor with minimal resuspension of surface sediments. These surficial sediment layers are essential when investigating bacterial activity, but are often poorly preserved during sampling (Tengberg et al., 2005). Experiments commenced with deposition of a dose of marine or terrigenous phytodetritus, equivalent to the annual POC input into bathyal and abyssal sediments in the NE Atlantic (Lampitt et al., 2001). Wheat was used as a model terrigenous POM source. However, the terrigenous OM accumulating in marine sediments is extensively degraded (e.g. Tesi et al., 2008) and so considerably less labile than the phytodetritus used within this study. The feeding responses of metazoan meio- fauna and foraminifera were not quantified within the present study. Meiofaunal contributions to benthic carbon budgets are relatively low, accounting for $<1 \%$ of ${ }^{13} \mathrm{C}$ uptake within stable-isotope labelling experiments (e.g. Witte et al., 2003b; Gontikaki et al., 2011b). Likewise, foraminiferal contributions to benthic carbon budgets typically occur over longer time periods (21-23 days) than the present study (e.g. Witte et al., 2003b; Nomaki et al., 2006). Experiments were conducted after the spring phytoplankton bloom, and so faunal and bacterial tracer uptake was relatively low compared with other ${ }^{13} \mathrm{C}$-labelling studies (e.g. Witte et al., 2003a, b; Sweetman and Witte 2008a, b; Gontikaki et al., 2011b). Whilst these data cannot be used to estimate an overall carbon budget, they describe the relative differences in faunal and bacterial feeding activity within the Whittard Canyon. Results were interpreted with caution, considering the limited replication available.

\subsection{Macrofaunal assemblages}

In the present study, macrofaunal densities were high at $\sim 3500 \mathrm{~m}$ depth, exceeding previous estimates made by Duineveld et al. (2001) at similar depths in the Whit-

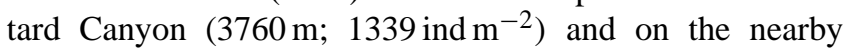
Goban Spur $\left(3600 \mathrm{~m} ; 2420\right.$ ind $\left.^{-2}\right)$. Abundances recorded in the present study were comparable with those observed by Cunha et al. (2011) at $\sim 3500 \mathrm{~m}$ in the Sebutal and Nazare canyons (2241-4599 ind $\mathrm{m}^{-2}$ ), and those recorded within bathyal sediments of the Faroe-Shetland Channel $\left(5166 \pm 1735\right.$ ind $^{-2}$ at $1080 \mathrm{~m}$; Gontikaki et al., 2011a), and western Norwegian fjords ( $4687 \pm 965$ ind m $^{-2}$ at $690 \mathrm{~m}, 2930 \pm 680 \mathrm{ind}^{-2}$ at $1300 \mathrm{~m}$; Witte et al., 2003a; Sweetman and Witte, 2008b). Benthic macrofaunal assemblages exhibited conspicuous differences between the Whittard canyons eastern and western branches. In the eastern branch, macrofaunal densities were higher, with macrofaunal-sized nematodes and both cirratulid and spionid polychaetes exhibiting greater contributions to assemblage structure. These taxa may be indicative of organic matter enrichment, oxygen limitation or disturbance within the sediment (Pearson and Rosenberg, 1978; Cunha et al., 2011; Paterson et al., 2011; Hunter et al., 2012a), occurring concomitantly with a richer assemblage of corals and associated fauna upon rocky substrata in the eastern branch (Huvenne et al., 2011). By contrast, the western branch macrofaunal assemblage was characterised by lower faunal densities and a greater contribution by crustaceans, such as the tanaids and macrofaunal-sized harpacticoid copepods. Therefore, the macrofaunal assemblage in the western canyon branch exhibits a similar composition to the macrobenthos found in the abyssal sediments of the Northeast Atlantic (Aberle and Witte, 2003). Differences in macrofaunal assemblage structure suggest differing regimes of disturbance and resource availability between the canyon branches. Higher abundance and the disturbance-tolerant taxa indicated greater frequency 

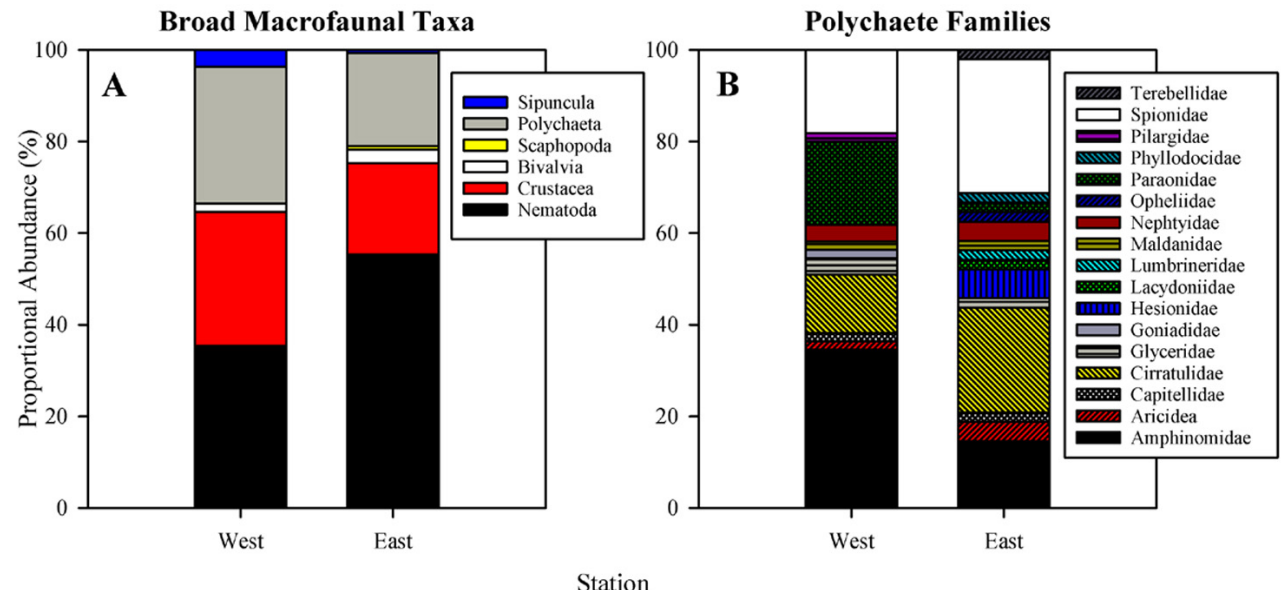

Fig. 4. Relative contributions of (A) the broad macrofauna taxa and (B) polychaete families to macrofaunal abundance at the eastern and western branch stations. Based upon 161 specimens at the West stations and 271 specimens at the East station.

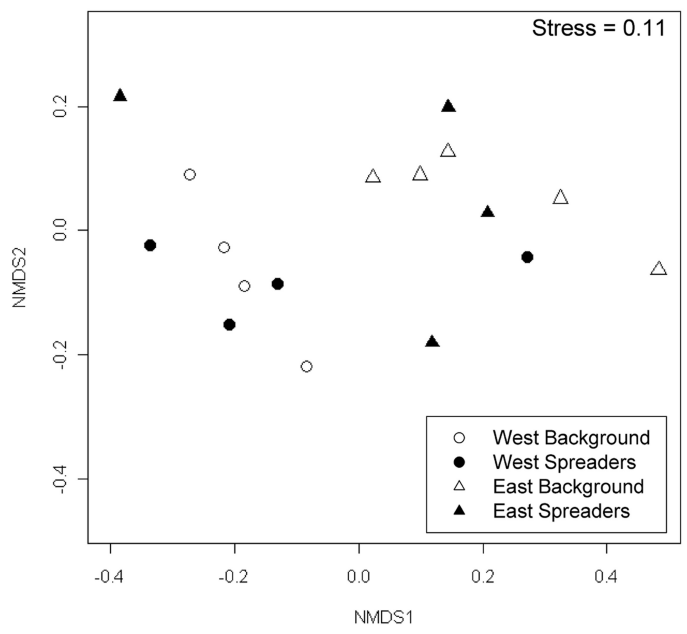

Fig. 5. NMDS ordination of the variation in macrofaunal assemblages at the two stations, calculated from Bray-Curtis dissimilarity matrices.

of disturbance events and potentially higher resource availability in the eastern branch (e.g. Cunha et al., 2011; Paterson et al., 2011). However, little difference in sediment OM content between stations (Table 1) highlights the intermittent nature of disturbance and sediment-deposition events in the Whittard Canyon.

$\mathrm{PO}^{13} \mathrm{C}$ and $\mathrm{PO}^{15} \mathrm{~N}$ profiles reveal subduction of the phytodetrital organic matter down to $5 \mathrm{~cm}$ in the sediments and little difference was observed between stations or experimental treatments. Previously rapid subduction of labelled OM down to $15 \mathrm{~cm}$ has been reported by maldanid polychaetes on the North Carolina margin by Levin et al. (1997). Sweetman and Witte $(2008 \mathrm{a}, \mathrm{b})$ demonstrate that over timescales less than 7 days, sediment mixing is restricted to the upper $5 \mathrm{~cm}$ of sediments in both a North Atlantic fjord and the abyssal

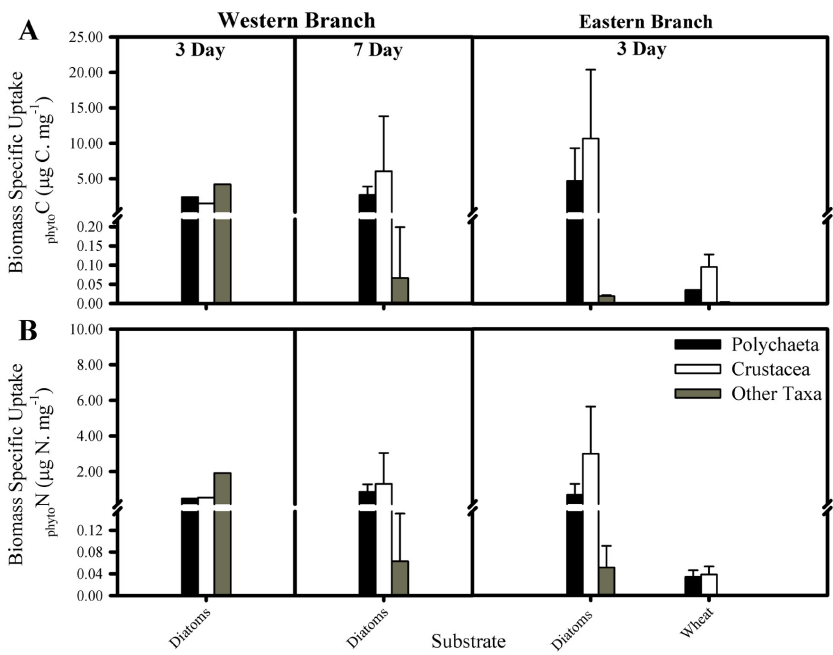

Fig. 6. Biomass-specific uptake of (A) phytodetrital carbon and (B) nitrogen by macrofaunal assemblages, following deposition of marine (diatoms) or terrigenous (wheat) phytodetritus over 3 and 7 days, at the east and west Whittard Canyon stations. Error bars represent data ranges

Pacific Ocean. It is hypothesised that macrofaunal subduction of OM is a behavioural adaptation to low food availability in abyssal sediments (Jumars et al., 1990). Fauna respond rapidly to phytodetritus deposition and by burying it, create a food store within the sediment out of potential competitors' reach. Thus, the presence of discretely motile depositfeeding polychaetes, such as the Amphinomidae and cirratulidae (Fauchald and Jumars, 1979), may account for the relatively homogenous mixing of phytodetrital OM throughout the sediments.

Benthic macrofaunal feeding responses are influenced by assemblage structure (Sweetman and Witte, 2008b; Hunter 


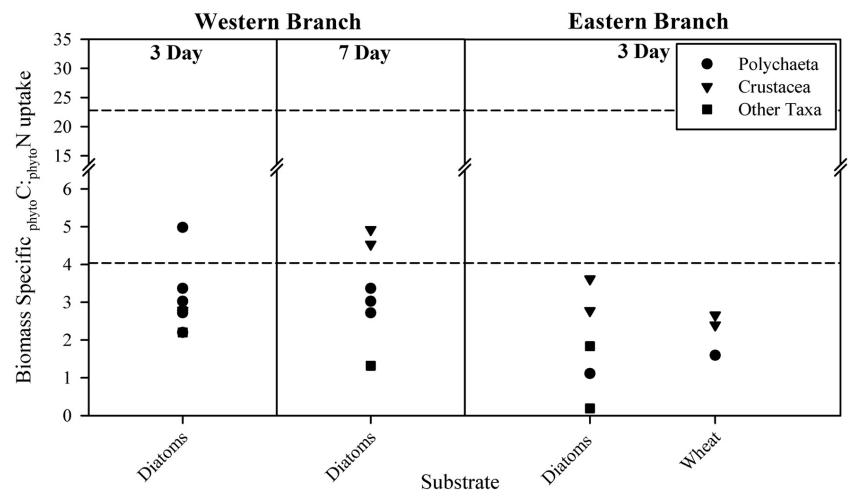

Fig. 7. C:N stoichiometry of Biomass-specific phyto $\mathrm{C}$ and phyto $^{\mathrm{N}}$ assimilation by macrofaunal assemblages, following deposition of marine (diatoms) or terrigenous (wheat) phytodetritus over 3 and 7 days, at the east and west Whittard Canyon stations. Dashed lines represent the $\mathrm{C}: \mathrm{N}$ ratios of diatoms (4.04) and wheat (22.80).

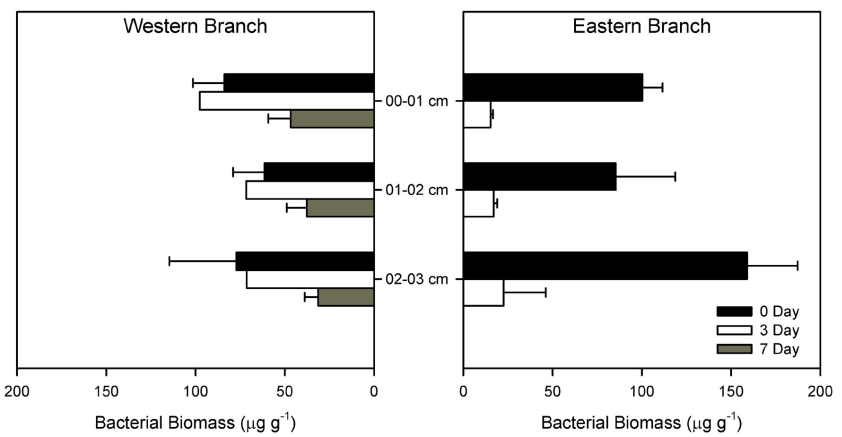

Fig. 8. Vertical distribution and changes in bacterial biomass over time at the western (mean \pm standard deviation) and eastern (mean \pm data range) branch stations. Bacterial biomass data is displayed per gram dry sediment.

et al., 2012a), with POM consumption proportional to faunal biomass (Middelburg et al., 2000). In order to provide comparable estimates of macrofaunal activity in the two canyon branches, phyto $\mathrm{C}$ and ${ }_{\text {phyto }} \mathrm{N}$ uptake were normalised to biomass. Between the eastern and western branches of the Whittard Canyon, differences in macrofaunal feeding activity reflected the high variability in macrofaunal biomass observed (Table B1), exhibiting no relationship with the observed differences in macrofaunal assemblage structure (Figs. 4 and 5). Within pulse-chase experiments, macrofaunal uptake of ${ }^{13} \mathrm{C}$-labelled phytodetritus is initially rapid, but net ${ }^{13} \mathrm{C}$ uptake may not increase over longer time periods (Woulds et al., 2009; Gontikaki et al., 2011a). In the western branch, macrofaunal uptake of both phyto $\mathrm{C}$ and phyto $\mathrm{N}$ changed little between 3 and 7 days, exhibiting a similar response to POM deposition as those observed in the abyssal NE Atlantic (Aberle and Witte, 2003; Witte et al., 2003b). However, slight increases in feeding activity by the crustaceans and decreased activity by other taxa further highlight

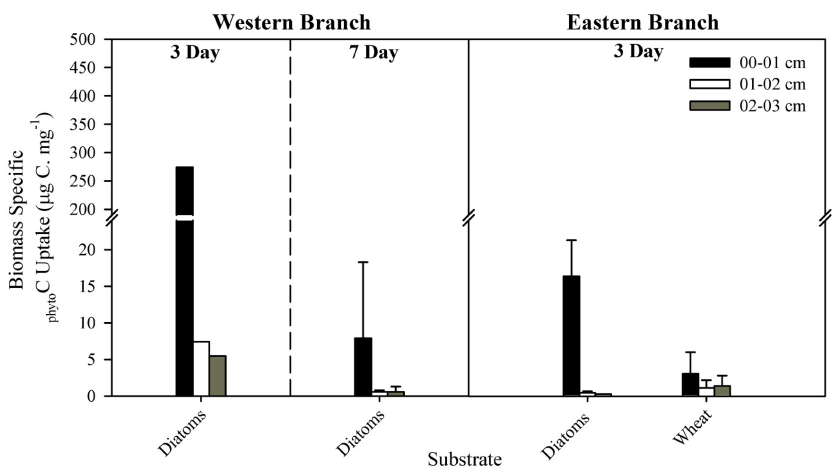

Fig. 9. Biomass-specific assimilation of phytodetrital carbon by bacterial assemblages, following deposition of marine (diatoms) or terrigenous (wheat) phytodetritus over 3 and 7 days, at the east and west Whittard Canyon stations. Error bars represent data ranges.

how variations in community structure and taxon-specific metabolic rates may influence macrofaunal contributions to benthic $\mathrm{C}$ and $\mathrm{N}$ cycling.

Faunal feeding responses are strongly influenced by the quantity and relative quality of OM introduced. The relative availability of nitrogenous organic compounds is an important predictor of organic matter availability (Hedges and Keil, 1995; Dauwe and Middelburg, 1998). Previous studies have demonstrated preferential consumption of organic nitrogen by benthic fauna (Evrard et al., 2010). Hunter et al. (2012a) demonstrate that macrofauna $\mathrm{C}$ and $\mathrm{N}$ assimilation are controlled by organismal C:N budgets. Experiments conducted in the eastern branch of the Whittard Canyon reveal dramatic differences in faunal phyto $\mathrm{C}$ and phyto $\mathrm{N}$ uptake, from marine and terrigenous POM sources. Terrigenous $\mathrm{OM}$ is typically nitrogen-poor relative to marine OM. Consequently, consumption of terrigenous phyto $\mathrm{C}$ and ${ }_{\text {phyto }} \mathrm{N}$ was low, compared with macrofaunal utilisation of marine OM. Faunal POM processing is controlled by organismal demands for organic $\mathrm{C}$, as an energy source, and nitrogenous compounds (e.g. amino acids), which are required for growth. These must be balanced against requirements to detoxify and excrete nitrogenous waste products (e.g. ammonia), resulting in strict C:N homeostasis (Frost et al., 2002, 2005). In both the eastern and western branches of the Whittard Canyon, phyto $\mathrm{C}$ :phyto $\mathrm{N}$ uptake ratios reveal a strong demand for $\mathrm{N}$ relative to the internal $\mathrm{C}: \mathrm{N}$ ratios of the fauna. As a result, macrofaunal utilisation of terrigenous OM was limited by the reduced availability of organic nitrogen, which alongside similar sediment mixing patterns across experimental treatments, suggests a mechanism for prolonged residence of terrigenous OM within canyon sediments. 

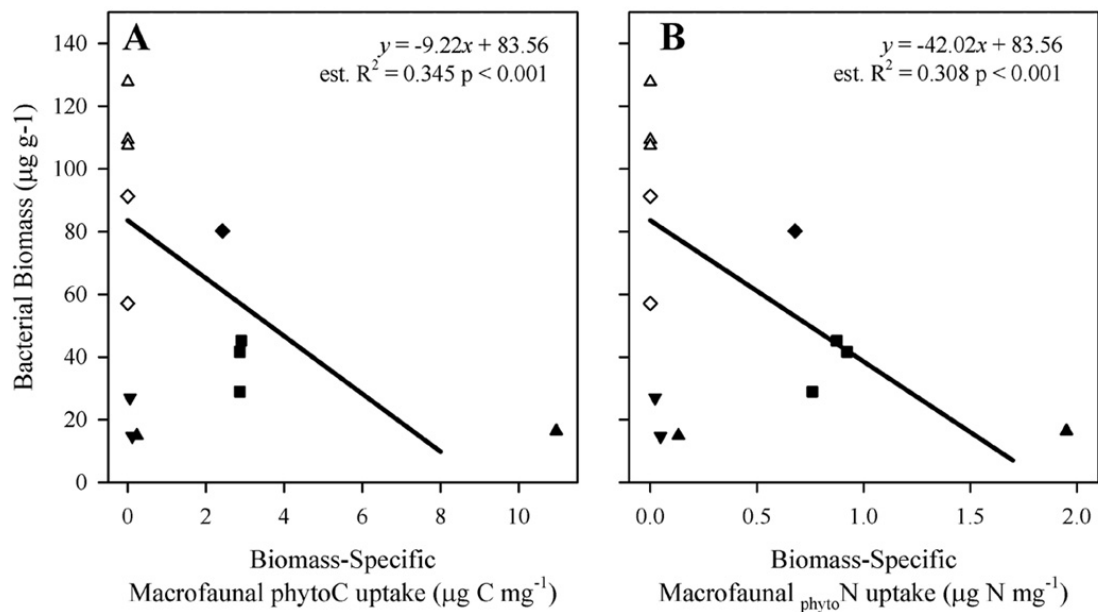

$\Delta \quad$ East Background $(0 \mathrm{~d})$

$\diamond \quad$ West Background $(0 \mathrm{~d})$

$\Delta \quad$ East Diatoms (3 d)

- East Wheat $(3 \mathrm{~d})$

- West Diatoms (3 d)

- West Diatoms (7 d)

Fig. 10. Scatter plots of bacterial biomass against biomass-specific uptake of (A) ${ }_{\text {phyto }} \mathrm{C}$ and (B) ${ }_{\text {phyto }}$ N. Regression lines in each plot were calculated using Theil-Sen single median regression.

\subsection{Bacterial responses and faunal-bacterial interactions}

The bacterial assemblages of the Whittard Canyon exhibit comparable levels of biomass with the bathyal and abyssal sediments of the Northeast Atlantic (Witte et al., 2003b; Duineveld et al., 2001). In both the eastern and western branches, bacterial biomass exhibited no vertical trends within the upper $3 \mathrm{~cm}$ of sediment, consistent with previous observations by Duineveld et al. (2001). Stable-isotope labelling experiments conducted in the Whittard Canyon's western branch reveal a decrease in bacterial phyto $\mathrm{C}$ assimilation between three and seven days. This contrasts with previous studies, which showed increased bacterial feeding activity over similar time periods at the Porcupine Abyssal Plain (Witte et al., 2003b) and Faroe-Shetland channel (Gontikaki et al., 2011b). Bacterial processing of POM occurs by extracellular hydrolysis. Extracellular enzyme production characterises the initial bacterial feeding response, and a time lag separates enzyme production from incorporation of OM into bacterial biomass (Boetius and Lochte, 1994, 1996). Thus, decreased bacterial phyto $\mathrm{C}$ assimilation between three and seven days may indicate inhibition of bacterial feeding activity, potentially mediated by faunal grazing or disturbance (e.g. Mojtahid et al., 2011).

In the Whittard Canyon's eastern branch, isotope labelling experiments reveal differences in bacterial incorporation of marine and terrigenous OM. Bacterial assimilation of marine $\mathrm{OM}$ was primarily restricted to the surficial $(0-1 \mathrm{~cm})$ sediment layers. Whilst assimilation of terrigenous $\mathrm{OM}$ was relatively low, it was used in greater proportions than marine $\mathrm{OM}$ in deeper sediment layers. Terrigenous OM is less labile than marine $\mathrm{OM}$, but bacterial assemblages are characterised by high metabolic and stoichiometric flexibility that allows them to process recalcitrant OM (Kristensen and Holmer,
2001; Mayor et al., 2012). These data support the hypothesis that resource-partitioning between macrofaunal and bacterial assemblages control OM recycling in marine sediments (Witte et al., 2003b; van Nugteren et al., 2009; Hunter et al., 2012b). Following a terrigenous phytodetritus deposition event, faunal bioturbation helps to subduct the POM into deeper sediment layers, and OM not directly used by the fauna is made available to the bacteria. This contrasts with the observed responses to marine OM, which is primarily used by macrofauna and the bacteria in surficial sediments, limiting its availability deeper in the sediments. Bacterial feeding activity also differed between the eastern and western branches, with higher uptake of phyto $\mathrm{C}$ recorded in the western branch. These observations reflect the differing oceanographic regimes of the two canyon branches, with the western branch receiving less-frequent inputs of sediment and organic matter from the continental shelf (Huvenne et al., 2011). Consequently, we hypothesise that the sediment community of the western branch may experience more pronounced resource-limitation, compared with the sediments in the eastern branch.

Bacterial biomass decreased following phytodetritus deposition and was negatively correlated to macrofaunal phyto $\mathrm{C}$ and ${ }_{\text {phyto }} \mathrm{N}$ assimilation, indicating that macrofaunal activity may regulate bacterial secondary production in the Whittard Canyon. Ecosystem models reveal relatively low direct energy flow between macrofauna and bacteria (Rowe et al., 2008; Van Oevelen et al., 2011a, b). Instead, faunal-bacterial interactions may occur through competition and resourcepartitioning, which limit bacterial access to organic matter source (van Nugteren et al., 2009; Hunter et al., 2012b), and faunal creation/destruction of microhabitats (Giblin et al., 1997). Low-level grazing by deposit feeders can control benthic bacterial production (Kemp, 1987), while Gontikaki et al. (2011c) suggest this is an intermediate link in 
Table A1. Background stable isotope signatures (mean \pm SD) for the sediment POM, bacterial PLFAs and main faunal taxa, at the eastern and western canyon stations. All data are presented in $\delta$ units $(\%)$ relative to the international standard reference material (Pee Dee Belemnite for ${ }^{13} \mathrm{C}$; Atmospheric Nitrogen for $\left.{ }^{15} \mathrm{~N}\right) \cdot \delta^{13} \mathrm{C}$ signatures of bacterial PLFAs were corrected to bacterial biomass $(+5 \%$ o following Hayes (2001).

\begin{tabular}{lll|ll}
\hline Station & \multicolumn{2}{c|}{ East } & \multicolumn{2}{c}{ West } \\
\hline & $\delta^{13} \mathrm{C}$ & $\delta^{15} \mathrm{~N}$ & $\delta^{13} \mathrm{C}$ & $\delta^{15} \mathrm{~N}$ \\
\hline Sediment POM & $-22.22( \pm 0.36)$ & $3.94( \pm 0.67)$ & $-22.04( \pm 0.56)$ & $4.09( \pm 2.42)$ \\
Bacteria & $-26.72( \pm 4.21)$ & & $-26.22( \pm 3.08)$ & \\
Polychaetes & $-20.72( \pm 0.72)$ & $10.22( \pm 1.43)$ & $-20.44( \pm 0.92)$ & $10.41( \pm 1.04)$ \\
Crustacea & $-20.09( \pm 1.04)$ & $12.09( \pm 2.74)$ & $-19.66( \pm 0.76)$ & $12.07( \pm 1.66)$ \\
Other Taxa & $-21.19( \pm 3.39)$ & $10.76( \pm 2.02)$ & $-21.66( \pm 1.82)$ & $10.16( \pm 2.60)$ \\
\hline
\end{tabular}

Table B1. Macrofaunal biomass in the eastern and western canyon branches.

\begin{tabular}{llll}
\hline Station & Taxa & $\begin{array}{l}\text { Biomass C } \\
\left(\mathrm{mg} \mathrm{C} \mathrm{m}^{-2}\right)\end{array}$ & $\begin{array}{l}\text { Biomass N } \\
\left(\mathrm{mg} \mathrm{C} \mathrm{m}^{-2}\right)\end{array}$ \\
\hline West & Polychaeta & $79.63( \pm 42.81)$ & $19.38( \pm 10.31)$ \\
& Crustacea & $15.60( \pm 19.54)$ & $3.64( \pm 4.06)$ \\
& Other Taxa & $10.19( \pm 7.61)$ & $2.67( \pm 1.89)$ \\
East & Polychaeta & $67.08( \pm 110.58)$ & $16.95( \pm 27.06)$ \\
& Crustacea & $28.82( \pm 22.71)$ & $6.62( \pm 5.16$ \\
& Other Taxa & $9.78( \pm 11.91)$ & $2.63( \pm 3.20)$ \\
\hline
\end{tabular}

the flow of carbon from detritus into the macrofauna. Observed correlations between faunal feeding activity and bacterial biomass, therefore, warrant further investigation via carefully designed manipulative experiments.

Given the decrease in bacterial biomass following phytodetritus deposition, the potential influence of benthic meiofaunal, foraminiferal and viral assemblages remain unquantified. Both meiofauna and foraminifera graze directly upon sediment bacteria (e.g. Nomaki et al., 2006; Pascal et al., 2008), and macrofaunal activity is known to directly influence the structure and activity of these other faunal groups (e.g. Giblin et al., 1995; Kristensen and Holmer, 2001; Nomaki et al., 2008). Consequently, interactions between the macrofauna and bacteria may occur via complex trophiccascades, alongside the direct interactions proposed in this study. Viral abundance is closely coupled to bacterial activity in marine sediments (e.g. Middelboe et al., 2003). This is because the bacteriophage life cycle shifts from dormancy to an infectious stage when nutrients are abundant (e.g. Gregory et al., 2010), which may result in $\sim 20 \%$ of benthic bacterial mortality (Glud and Middelboe, 2004). Given the importance of bacteria within benthic C budgets (Witte et al., 2003a, b; Gontikaki et al., 2011a), and high viral densities in deep-sea sediments (Danovaro et al., 2008), it is reasonable to speculate that viral lysis may contribute to the observed decrease in bacterial biomass. Therefore, the present results may high- light both faunal-bacterial and bacterial-viral interactions as understudied pathways within deep-sea $\mathrm{C}$ and $\mathrm{N}$ cycles.

\section{Conclusions}

In situ stable-isotope labelling experiments reveal how macrofaunal and bacterial activity influences the short-term processing of marine and terrigenous OM, in submarine canyon sediments. Macrofaunal feeding activity exhibited no changes between 3 and 7 days, but significant differences in phyto $\mathrm{C}$ and ${ }_{\text {phyto }} \mathrm{N}$ uptake were observed between marine and terrigenous OM treatments. These were controlled by a strong internal $\mathrm{N}$ demand, in the macrofauna, possibly limiting their utilisation of the N-poor terrigenous OM. Bacterial phyto $\mathrm{C}$ incorporation was influenced by faunal activity, which appears to mediate the availability of OM within the sediments, and is negatively correlated to bacterial biomass. This indicates that macrofaunal grazing and microhabitat destruction may inhibit bacterial OM processing. However, it remains uncertain whether these observations are driven by a causal relationship and potential macrofauna-bacterial interactions require investigation within a manipulative experimental framework.

Acknowledgements. The authors gratefully acknowledge the help and support of the officers and crew of the RRS James Cook and ROV ISIS, Doug Masson and the scientific team during cruise JC036. We also acknowledge Margarita Machairopoulou (U. Aberdeen), for her assistance with macrofaunal sorting and identification, and Val Johnston (U. Aberdeen). Darryl Green and Jez Evans (NOC, Southampton) assisted with the shipment of equipment, chemicals and samples. The authors thank David Harris (UC Davis Stable Isotope Facility), Barry Thornton and Maureen Procee (James Hutton Institute) for their assistance with stable-isotope analysis. This study forms part of the FP7 EU HERMIONE project (Hotspot Ecosystem Research and Man's Impact on European seas, grant agreement number: 226354). WRH was supported by a NERC Doctoral Training Grant (NE/G523904/1).

Edited by: R. S. Santos 


\section{References}

Aberle, N. and Witte, U.: Deep-sea macrofauna exposed to a simulated sedimentation event in the abyssal NE Atlantic: in situ pulse-chase experiments using ${ }^{13} \mathrm{C}$-labelled phytodetritus, Mar. Ecol. Prog. Ser., 251, 37-47, 2003.

Anderson, M. J.: Distance-based tests for homogeneity of multivariate dispersions, Biometrics, 62, 245-253, 2006.

Anderson, M. J.: A new method for non-parametric multivariate analysis of variance, Aust. Ecol., 26, 32-46, 2011.

Arzola, R. G., Wynn, R. B., Lastras, G., Masson, D. G., and Weaver, P. P. E.: Sedimentary features and processes in the Nazareì and Setuìbal submarine canyons, west Iberian margin, Mar. Geol., 250, 64-88, 2008.

Billett, D. S. M., Lampitt, R. S., Rice, A. L., and Mantoura, R. F. C.: Seasonal Sedimentation of Phytoplankton to the Deep-Sea Benthos, Nature, 302, 520-522, 1983.

Boetius, A. and Lochte, K.: Regulation of microbial enzymatic degradation of organic matter in deep-sea sediments, Mar. Ecol. Prog. Ser., 104, 299-307, 1994.

Boetius, A. and Lochte, K.: Effects of organic enrichment on hydrolytic potentials and growth of bacteria in deep-sea sediments, Mar. Ecol. Prog. Ser., 140, 239-250, 1996.

Boschker, H. T. S. and Middelburg, J. J.: Stable isotopes and biomarkers in microbial ecology, FEMS Microbiol. Ecol., 40, 85-95, 2002.

Boschker, H. T. S., Nold, S. C., Wellsbury, P., Bos, D., de Graaf, W., Pel, R., Parkes, R. J., and Cappenberg, T. E.: Direct linking of microbial populations to specific biogeochemical processes by ${ }^{13}$ C-labelling of biomarkers, Nature, 392, 801-805, 1998.

Brinch-Iversen, J. and King, G. M.: Effects of substrate concentration, growth state, and oxygen availability on relationships among bacterial carbon, nitrogen and phospholipid phosphorus content, FEMS Microbiol. Lett., 74, 345-355, 1990.

Buhring, S. I., Lampadariou, N., Moodley, L., Tselepides, A., and Witte, U.: Benthic microbial and whole-community responses to different amounts of ${ }^{13} \mathrm{C}$-enriched algae: In situ experiments in the deep Cretan Sea (Eastern Mediterranean), Limnol. Oceanogr., 51, 157-165, 2006.

Canals, M., Puig, P., De Madron, X. D., Heussner, S., Palanques, A., and Fabres, J.: Flushing submarine canyons, Nature, 444, 354357, 2006.

Clarke, K. R.: Non-parametric multivariate analyses of changes in community structure, Aust. J. Ecol., 18, 117-143, 1993.

Crossman, Z. M., Abraham, F., and Evershed, R. P.: Stable isotope pulse-chasing and compound specific stable carbon isotope analysis of phospholipid fatty acids to assess methane oxidizing bacterial populations in landfill cover soils, Environ. Sci. Technol., 38, 1359-1367, 2004.

Cunha, M. R., Paterson, G. L. J., Amaro, T., Blackbird, S., de Stigter, H. C., Ferreira, C., Glover, A., Hilário, A., Kiriakoulakis, K., Neal, L., Ravara, A., Rodrigues, C. F., Tiago, Á., and Billett, D. S. M.: Biodiversity of macrofaunal assemblages from three Portuguese submarine canyons (NE Atlantic), Deep-Sea Res. Pt. II, 58, 2433-2447, 2011.

Cunningham, M. J., Hodgson, S., Masson, D. G., and Parson, L. M.: An evaluation of along- and down-slope sediment transport processes between Goban Spur and Brenot Spur on the Celtic Margin of the Bay of Biscay, Sed. Geol., 179, 99-116, 2005.
Danavaro, R., Dell'Anno, A., Corinaldesi, C., Magagnini, M., Noble, R., Tanburini, C., and Weinbauer, M.: Major viral impact on the functioning of benthic deep-sea ecosystems, Nature, 454, 1084-1087, 2008.

Dauwe, B. and Middelburg, J. J.: Amino acids and hexosamines as indicators of organic matter degradation state in North Sea sediments, Limnol. Oceanogr., 43, 782-798, 1998.

De Leo, F. C., Smith, C. R., Rowden, A. A., Bowden, D. A., and Clark, M. R.: Submarine canyons: hotspots of benthic biomass and productivity in the deep sea, Proc. Roy. Soc. Ser. B, 277, 2783-2792, 2010.

de Stigter, H. C., Boer, W., de Jesus Mendes, P. A, Jesus, C. C., Thomsen, L., van den Bergh, G. D., and van Weering, T. C. E.: Recent sediment transport and deposition in the Nazaré Canyon, Portuguese continental margin, Mar. Geol., 246, 144-164, 2007.

Duineveld, G., Lavaleye, M., Berghuis, E., and De Wilde, P.: Activity and composition of the benthic fauna in the Whittard Canyon and the adjacent continental slope (NE Atlantic), Oceanol. Acta, 24, 69-83, 2001.

Duros, P., Fontanier, C., Metzger, E., Pusceddu, A., Cersbron, F., de Stitger, H.C., Bianchelli, S., Danovaro, R., and Jorissen, F. L.: Live (stained) benthic foraminifera in the Whittard Canyon, Celtic margin (NE Atlantic), Deep-Sea Res. Pt. I, 58, 128-146, 2011.

Escobar-Briones, E., Estrada Santillaìn, E. L., and Legendre, P.: Macrofaunal density and biomass in the Campeche Canyon, Southwestern Gulf of Mexico, Deep-Sea Res. Pt. II, 55, 26792685, 2008.

Evrard, V., Soetaert, K., Heip, C. H. R., Huettel, M., Xenopoulos, M. A., and Middelburg, J. J.: Carbon and nitrogen flows through the benthic food web of a photic subtidal sandy sediment, Mar. Ecol. Prog. Ser., 416, 1-16, 2010.

Fauchald, K. and Jumars, P. A.: The Diet of Worms: a study of polychaete feeding guilds, Oceanogr. Mar. Biol. Ann. Rev., 17, 193284, 1979.

Frost, P. C., Stelzer, R. S., Lamberti, G. A., and Elser, J. J.: Ecological stoichiometry of trophic interactions in the benthos: Understanding the role of C:N:P ratios in lentic and lotic habitats, J. N. Am. Benthol. Soc., 21, 515-528, 2002.

Frost, P. C., Evans-White, M. A., Finkel, Z. V., Jensen, T. C., and Matzek, V.: Are you what you eat?, Physiological constraints on organismal stoichiometry in an elementally imbalanced world, Oikos, 109, 18-28, 2005.

Giblin, A. E., Foreman, K. H., and Banta, G. T.: Biogeochemical processes and marine benthic community structure: which follows which?, in: Linking Species and Ecosystems, Chapman and Hall, New York, USA, 29-36, 1995.

Glud, R. N. and Middelboe, M.: Virus and bacteria dynamics of a coastal sediment: Implications for benthic carbon cycling, Limnol. Oceanogr., 49, 2073-2081, 2004.

Gontikaki, E., Mayor, D. J., Narayanaswamy, B. E., and Witte, U.: Feeding strategies of deep-sea sub-Arctic macrofauna of the Faroe-Shetland Channel: Combining natural stable isotopes and enrichment techniques, Deep-Sea Res. Pt. I, 58, 160-172, 2011a.

Gontikaki, E., Mayor, D. J., Thornton, B., Black, K., and Witte, U.: Processing of ${ }^{13} \mathrm{C}$-labelled diatoms by a bathyal community at sub-zero temperatures, Mar. Ecol. Prog. Ser., 421, 39-50, 2011 b.

Gontikaki, E., van Oevelen, D., Soetaert, K., and Witte, U.: Food web flows through a sub-arctic deep-sea benthic community, 
Prog. Oceanogr., 91, 245-259, 2011c.

Gooday, A. J.: Biological responses to seasonally varying fluxes of organic matter to the ocean floor: A review, J. Oceanogr., 58, 305-332, 2002.

Gregory, R., Saunders, V. A., and Saunders, J. R.: Rule-based simulation of temperate bacteriophage infection: Restrictionmodification as a limiter to infection in bacterial populations, Bio Sys, 100, 166-177, 2010.

Hall, P. O. J., Brunnegard, J., Hulthe, G., Martin, W. R., Stahl, H., and Tengberg, A.: Dissolved organic matter in abyssal sediments: Core recovery artefacts, Limnol. Oceanogr., 52, 19-31, 2007.

Harris, P. T. and Whiteway, T.: Global distribution of large submarine canyons: Geomorphic differences between active and passive continental margins, Mar. Geol., 285, 69-86, 2011.

Hayes, J. M.: Fractionation of the isotopes of carbon and hydrogen in biosynthetic processes, in: Stable Isotope Geochemistry, Reviews in Mineralogy and Geochemistry, edited by: Valley, J. W. and Cole, D. R., Washington DC, Min. Soc. Ser. Am., 43, 225278, 2001.

Hedges, J. I. and Keil, R. G.: Sedimentary organic matter preservation: an assessment and speculative synthesis, Mar. Chem., 49, 81-115, 1995.

Hedges, J. I. and Stern, J. H.: Carbon and nitrogen determinations of carbonate-containing solids, Limnol. Oceanogr., 29, 657-663, 1984.

Hunter, W. R., Levin, L. A., Kitazato, H., and Witte, U.: Macrobenthic assemblage structure and organismal stoichiometry control faunal processing of particulate organic carbon and nitrogen in oxygen minimum zone sediments, Biogeosciences, 9, 993-1006, doi:10.5194/bg-9-993-2012, 2012a.

Hunter, W. R., Veuger, B., and Witte, U.: Macrofauna regulate heterotrophic bacterial carbon and nitrogen incorporation in lowoxygen sediments, ISME J., 6, 2140-2151, 2012b.

Huvenne, V. A. I., Tyler, P. A., Masson, D. G., Fisher, E. H., Hauton, C., Hühnerbach, V., Le Bas, T., and Wolff, G. A.: A picture on the wall: innovative mapping reveals cold-water coral refuge in submarine canyon, PLoS One, 6, e28755, doi:10.1371/journal.pone.0028755, 2011.

Jumars, P. A., Mayer, L. M., Deming, J. W., Baross, J. A., and Wheatcroft, R. A.: Deep-Sea Deposit-Feeding Strategies Suggested by Environmental and Feeding Constraints, Phil. Trans. Roy. Soc. Ser. A, 331, 85-101, 1990.

Kaehler, S. and Pakhomov, E. A.: Effects of storage and preservation on the $\delta^{13} \mathrm{C}$ and $\delta^{15} \mathrm{~N}$ signatures of selected marine organisms, Mar. Ecol. Prog. Ser., 219, 299-304, 2001.

Kemp, P. F.: Potential impact on bacteria of grazing by a macrofaunal deposit-feeder, and the fate of bacterial production, Mar. Ecol. Prog. Ser., 36, 151-161, 1987.

Komsta, L.: Median-based Linear Models, 0.11, 2007.

Kristensen, E. and Holmer, M.: Decomposition of plant materials in marine sediment exposed to different electron acceptors $\left(\mathrm{O}_{2}\right.$, $\mathrm{NO}_{3}^{-}$, and $\mathrm{SO}_{4}^{-2}$ ) with emphasis on substrate origin, degradation kinetics, and the role of bioturbation, Geochim. Cosmochim. Ac., 65, 1404-1419, 2001.

Lampitt, R. S., Bett, B. J., Kiriakoulakis, K., Popova, E. E., Ragueneau, O., Vangriesheim, A., and Wolff, G. A.: Material supply to the abyssal seafloor in the northeast Atlantic, Prog. Oceanogr., 50, 27-63, 2001.
Levin, L., Blair, N., DeMaster, D., Plaia, G., Fornes, W., Martin, C., and Thomas, C.: Rapid subduction of organic matter by maldanid polychaetes on the North Carolina slope, J. Mar. Res., 55, 595611, 1997.

Mayor, D. J., Thornton, B., Hay, S., Zuur, A. F., Nicol, G., McWilliams, J. M., and Witte, U. F. M.: Resource quality affects carbon cycling in deep-sea sediments, ISME J., 6, 1740-1748, 2012.

Middelboe, M., Glud, R. N., and Finster, K.: Distribution of viruses and bacteria in relation to diagenetic activity in an estuarine sediment, Limnol. Oceanogr., 48, 1447-1456, 2003.

Middelburg, J. J., Barranguet, C., Boschker, H. T. S., Herman, P. M. J., Moens, T., and Heip, C. H. R.: The fate of intertidal microphytobenthos carbon: An in situ ${ }^{13} \mathrm{C}$-labeling study, Limnol. Oceanogr., 45, 1224-1234, 2000.

Mojtahid, M., Zubkov, M. V., Hartmann, M., and Gooday, A. J.: Grazing of intertidal benthic foraminifera on bacteria: Assessment using pulse-chase radiotracing, J. Exp. Mar. Biol. Ecol., 399, 25-34 2011.

Nomaki, H., Heinz, P., Nakatsuka, T., Simanaga, M., Ohkouchi, N., Ogawai, N. O., Kogure, K., Ikemoto, E., and Kitazato, H.: Different ingestion patterns of ${ }^{13} \mathrm{C}$-labeled bacteria and algae by deep-sea benthic foraminifera, Mar. Ecol. Prog. Ser., 310, 95108, 2006.

Nomaki, H., Ogawa, N. O., Ohkouchi, N., Suga, H., Toyofuku, T., Shimanaga, M., Nakatsuka, T., and Kitazato, H.: Benthic foraminifera as trophic links between phytodetritus and benthic metazoans: carbon and nitrogen isotopic evidence, Mar. Ecol. Prog. Ser., 357, 153-164, 2008.

Oksanen, J., Kindt, R., Legendre, P., O’Hara, B., Simpson, G. L., Solymos, P. M., Stevens, H. H., and Wagner, H.: vegan: Community Ecology Package, 1.15-4, 2009.

Otto, S. and Balzer, W.: Release of dissolved organic carbon (DOC) from the sediments of the N.W. European Continental Margin (Goban Spur) and its significance for benthic carbon cycling, Prog. Oceanogr., 42, 127-144, 1998.

Pascal, P.-Y., Dupuy, C., Richard, P., Rzeznik-Orignac, J., and Nipuil, N.: Bacterivory of a mudflat nematode community under different environmental conditions, Mar. Biol., 154, 671-682, 2008.

Pasqual, C., Lee, C., Goni, M., Tesi, T., Sanchez-Vidal, A., Calafat, A., Canals, M., and Heussner, S.: Use of organic biomarkers to trace the transport of marine and terrigenous organic matter through the southwestern canyons of the Gulf of Lion, Mar. Chem., 126, 1-12, 2011.

Paterson, G. L. J., Glover, A. G., Cunha, M. R., Neal, L., de Stigter, H. C., Kiriakoulakis, K., Billett, D. S. M., Wolff, G. A., Ravara, A., Lamont, P., and Tyler, P.: Disturbance, productivity and diversity in deep-sea canyons: A worm's eye view, Deep-Sea Res. Pt. II, 58, 2448-2460, 2011.

Pearson, T. H. and Rosenberg, R.: Macrobenthic succession in relation to organic enrichment and pollution of the marine environment, Oceanogr. Mar. Biol. Ann. Rev., 16, 229-311, 1978.

Quinn, G. P. and Keough, M. J.: Experimental Design and Data Analysis for Biologists, Cambridge University Press, Cambridge, 2002.

R Development Core Team: R: A language and environment for statistical computing, R Foundation for Statistical Computing, 2009. 
Rabouille, C., Caprais, J. C., Lansard, B., Crassous, P., Dedieu, K., Reyss, J. L., and Khripounoff, A.: Organic matter budget in the Southeast Atlantic continental margin close to the Congo Canyon: In situ measurements of sediment oxygen consumption, Deep-Sea Res. Pt. II, 56, 2223-2238, 2009.

Rajendran, N., Suwa, Y., Urushigawa, Y., and Simidu, U.: Distribution of phospholipid ester-linked fatty acid biomarkers for bacteria in the sediments of Ise Bay, Japan, Mar. Chem., 42, 39-56, 1993.

Rajendran, N., Matsuda, O., Urushigawa,Y., and Simidu, U.: Characterization of microbial community structure in the surface sediment of Osaka Bay, Japan, by phospholipid fatty acid analysis, App. Environ. Microbiol., 60, 248-257, 1994.

Reid, G. S. and Hamilton, D.: A reconnaissance survey of the Whittard Sea Fan, Southwestern Approaches, British Isles, Mar. Geol., 92, 69-86, 1990.

Rowe, G. T., Wei, C. L., Nunnally, C., Haedrich, R., Montagna, P., Baguley, J. G., Bernhard, J. M., Wicksten, M., Ammons, A., Briones, E. E., Soliman, Y., and Deming, J. W.: Comparative biomass structure and estimated carbon flow in food webs in the deep Gulf of Mexico, Deep-Sea Res. Pt. II, 55, 2699-2711, 2008.

Sen, P. K.: Estimates of Regression Coefficient Based on Kendall's tau, J. Am. Stat. Ass., 63, 1379-1389, 1968.

Smith, K. L., Ruhl, H. A., Bett, B. J., Billett, D. S. M., Lampitt, R. S., and Kaufmann, R. S.: Climate, carbon cycling, and deepocean ecosystems, Proc. Natl. Acad. Sci., 106, 19211-19218, 2010.

Stoeck, T., Kröncke, I., Duineveld, G. C. A., and Palojärvi, A.: Phospholipid fatty acid profiles at depositional and nondepositional sites in the North Sea, Mar. Ecol. Prog. Ser., 241, 57-70, 2002.

Sweetman, A. K. and Witte, U.: Response of an abyssal macrofaunal community to a phytodetrital pulse, Mar. Ecol. Prog. Ser., 355, 73-84, 2008a.

Sweetman, A. K. and Witte, U.: Macrofaunal response to phytodetritus in a bathyal Norwegian fjord, Deep-Sea Res. Pt. I, 55, 1503-1514, 2008b.

Tengberg, A., Hall, P. O. J., Andersson, U., Linden, B., Styrenius, O., Boland, G., de Bovee, F., Carlsson, B., Ceradini, S., Devol, A., Duiniveld, G., Friemann, J.-U., Glud, R. N., Khripounoff, A., Leather, A., Linke, P., Lund-Hansen, L., Rowe, G., Santschi, P., de Wilde, P., and Witte, U.: Intercalibration of benthic flux chambers II. Hydrodynamic characterization and flux comparisons of 14 different designs, Mar. Chem., 94, 147-173, 2005.

Tesi, T., Langone, L., Goñi, M. A., Turchetto, M., Miserocchi, S., and Boldrin, A.: Source and composition of organic matter in the Bari canyon (Italy): Dense water cascading versus particulate export from?the upper ocean, Deep-Sea Res. Pt. I, 55, 813-831, 2008.

Tesi, T., Puig, P., Palanques, A., and Goñi, M. A.: Lateral advection of organic matter in cascading-dominated submarine canyons, Prog. Oceanogr., 84, 185-203, 2010.

Thingstad, T. F.: Utilization of N, P, and organic C by heterotrophic bacteria, I, outline of a chemostat theory with a consistent concept of "maintenance" metabolism, Mar. Ecol. Prog. Ser., 35, 99109, 1987.
Toucanne, S., Zaragosi, S., Bourillet, J.-F., Naughton, F., Cremer, M., Eynaud, F., and Denielou, B.: Activity of the turbidite levees of the Celtic-Armorican margin (Bay of Biscay) during the last 30000 years: imprints of the last European deglaciation and Heinrich events, Mar. Geol., 247, 84-103, 2008.

van Nugteren, P., Herman, P. M. J., Moodley, L., Middelburg, J. J., Vos, M., and Heip, C. H. R.: Spatial distribution of detrital resources determines the outcome of competition between bacteria and a facultative detritivorous worm, Limnol. Oceanogr., 54, 1413-1419, 2009.

van Oevelen, D., Soetaert, K., Middelburg, J. J., Herman, P. M. J., Moodley, L., Hamels, I., Moens, T., and Heip, C.: Carbon flows through a benthic food web: Integrating biomass, isotope and tracer data, J. Mar. Res., 64, 453-482, 2006.

van Oevelen, D., Bergmann, M., Soetaert, K., Bauerfeind, E., Hasemann, C., Klages, M., Schewe, I., Soltwedel, T., and Budeva, N. E.: Carbon flows in the benthic food web at the deep-sea observatory HAUSGARTEN (Fram Strait), Deep-Sea Res. Pt. I, 58, 1069-1083, 2011a.

van Oevelen, D., Soetaert, K., Garcia, R., de Stigter, H. C., Cunha M. R., Pusceddu, A., and Danavaro, R.: Canyon conditions impact carbon flows in food webs of three sections of the Nazaré canyon, Deep-Sea Res. Pt. II, 58, 2461-2476, 2011 b.

Venables, W. N. and Ripley, B. D.: Modern Applied Statistics with S. Springer, New York, 2002.

Vetter, E. W. and Dayton, P. K.: Macrofaunal communities within and adjacent to a detritus-rich submarine canyon system, DeepSea Res. Pt. II, 45, 25-54, 1998.

Vitousek, P. M. and Howarth, R. W.: Nitrogen limitation on land and in the sea: how can it occur?, Biogeochem., 13, 87-115, 1991.

White, D. C., Davis, W. M., Nickels, J. S., King, J. D., and Bobbie, R. J.: Determination of the sedimentary microbial biomass by extractable lipid phosphate, Oecologia, 40, 51-62, 1979.

Witte, U., Aberle, N., Sand, M., and Wenzhofer, F.: Rapid response of a deep-sea benthic community to POM enrichment: an in situ experimental study, Mar. Ecol. Prog. Ser., 251, 27-36, 2003a.

Witte, U., Wenzhofer, F., Sommer, S., Boetius, A., Heinz, P., Aberle, N., Sand, M., Cremer, A., Abraham, W.-R., Jørgensen, B. B., and Pfannkuche, O.: In situ experimental evidence of the fate of a phytodetritus pulse at the abyssal sea floor, Nature, 424, 763766, 2003b.

Woulds, C., Andersson, J. H., Cowie, G. L., Middelburg, J. J., and Levin, L. A.: The short-term fate of organic carbon in marine sediments: Comparing the Pakistan margin to other regions, DeepSea Res. Pt. II, 56, 393-402, 2009.

Zaragosi, S., Bourillet, J.-F., Eynaud, F., Toucanne, S., Denhard, B., Van Toert, A., and Lanfumey, V.: The impact of the last European deglaciation on the deep-sea turbidite systems of the CelticArmorican margin (Bay of Biscay), Geo.-Mar. Lett., 26, 317329, 2006.

Zuur, A. F., Ieno, E. N., and Elphick, C. S.: A protocol for data exploration to avoid common statistical problems, Meth. Ecol. Evol., 1, 3-14, 2010. 